Early childhood education for sustainability: origins and inspirations in the work of John Dewey

Paulette Luff

Department of Education, Anglia Ruskin University, Chelmsford, UK

paulette.luff@anglia.ac.uk

Dr Paulette Luff is a Senior Lecturer at Anglia Ruskin University where she is course leader for the MA Early Childhood Education and convener for the Early Childhood Research Group.

NB The Version of Record of this manuscript has been published and is available in Education 3-13 2018 ISSN 1475-7575 DOI 10.1080.03004279.2018.1445484 


\section{Early childhood education for sustainability: origins and inspirations in the work}

\section{of John Dewey}

In this article, the work of John Dewey is recontextualised and proposed as a basis for contemporary early childhood education for sustainability (ECEfS). Five key themes are explored: experiential learning; curiosity and critical thinking; children's experiences in nature; democracy and participation; and classroom as community. In each case, claims are made through aligning the work of Dewey with exemplars from current early childhood practice. The focus is reflection upon the educator as facilitator of dynamic interactions between the learner and her/his experiences, fostering individual growth, influencing social change and, thus, creating possibilities for implementation of ECEfS within early years classrooms.

Keywords: Dewey; education for sustainability; early childhood

\section{Introduction}

The argument presented in this paper is that the work of John Dewey provides a basis for contemporary education for sustainability, particularly for those working with the youngest children. The many spheres of life to which Dewey gave attention and his commitment to positive growth and change, rooted in experience, hold continuing promise as a philosophy of sustainability for the 21st century (Hildebrand, 2008; Garrison et al, 2014). In parallel, Dewey's ideas have long provided inspiration for early childhood educators, providing a rationale for pedagogies based upon observing children's interests and for sharing of experience in practical, social activities (for example, and notably, Cuffaro, 1995). Bringing these viewpoints together, Deweyan ideals and ideas offer great promise as a theoretical and practical basis for early childhood education for sustainability (ECEfS). Garrison (2008) identifies Dewey as an advocate of reconstruction who recognised the need for ideas to be recreated, according to context; and whose philosophy can usefully be reconceptualised and applied within new and changing times and places. 
This provides inspiration for the recontextualising of Deweyan thought as a source of insight for ECEfS today.

Education for Sustainability features in debates across all sectors of education, perhaps increasingly with the introduction of global Sustainable Development Goals (United Nations 2015). The UN Decade of Education for Sustainable Development (ESD), from 2005-2014, focused upon formal and informal education as a route towards a more sustainable future. As part of this initiative, the Gothenburg Recommendations (UNESCO 2008) called upon early childhood educators to prioritise processes to develop and strengthen sustainable development. In some early childhood curricula there is now explicit mention of sustainability, in the Australian Early Years Learning Framework (EYLF) (Commonwealth of Australia, 2009), for example, it states: 'Environments and resources can also highlight our responsibilities for a sustainable future and promote children's understanding about their responsibility to care for their environment' (16) and educators are required to embed sustainable practices in daily routines and procedures. In many other places, including the Early Years Foundation Stage (EYFS) (DfE, 2017), in England, engagement with and care for the environment is a part of early learning.

It is, however, more challenging to design age-appropriate pedagogical experiences that encompass wider aspects of sustainability: not only environmental concerns but also social issues (including human rights, inclusion and conflict resolution) and economic challenges (such as responsible use of resources and reduction of poverty and inequalities). This was recognised in a report to the European Union (EPSD, 2010) that highlighted the capacities of young children to engage with complex issues and recommended that ESD should be an integral part of training and professional development for pre-school educators (EPSD, 2010). This has been addressed, in a practical manner, by the OMEP (Organisation Mondiale pour 1'Education Prescolaire / 
World Organization for Early Childhood Education World Project, that is designed to raise awareness of Education for Sustainable Development within and beyond the international early childhood community (Siraj-Blatchford et al, 2010; Engdahl, 2015; Siraj-Blatchford et al, 2016). The various activities associated with this initiative are child-oriented and capture children's thoughts and ideas for action for ESD, including intergenerational dialogues and projects to address inequalities (Engdahl, 2015).

It is within this context that reconstruction of Deweyan ideals and ideas, as a theoretical and practical basis for early childhood education for sustainability (ECEfS), is proposed. The approach adopted is one of Deweyan reflective thinking (Dewey, 1933; Rodgers, 2002). It is a process of meaning making in which I connect my current knowledge of the work of John Dewey with a wholehearted commitment to ECEfS in order to deepen understandings of both. This is an ongoing process and, thus, what is presented here is a work in progress and intended as a basis for further exploration and experimentation. In the light of this, five key topics are discussed: experiential learning; curiosity and critical thinking; children's experiences in nature; democracy and participation; and early years classroom as community. In each case, claims are made through recontextualising the work of Dewey to link insights from his work with contemporary early childhood research and practice. Throughout, the focus is upon the

educator as facilitator of dynamic interactions between the learner and her/his experiences, fostering individual growth and aspiring to influence social change (Dewey, 1916) and furthering possibilities for implementation of ECEfS within early years classrooms.

\section{Experiential Learning}

Experiential learning is at the heart of early childhood education. Learning through play and active exploration of the environment allow for processes of knowledge construction, 
occurring within specific social, cultural and ecological contexts. Teachers observe children's interests and aptitudes in order to understand their past and current experience and to provide worthwhile new experiences. This supports children to integrate new experiences with their existing knowledge and to develop novel insights and judgements, to form a basis for further action (Dewey, 1916, 1933). Following a recommendation in the Tickell Review $(2011,27)$, 'playing and exploring, active learning, and creating and thinking critically' have been emphasised as characteristics of early learning. This highlights the distinctive features of experiential learning that are central to practice within the EYFS curriculum, where the optimal development of each unique child is fostered through positive relationships within an enabling environment (DfE, 2017).

In terms of ECEfS, this attention to experience is central. The environments and interactions provided for young children are influential for their present and future beliefs, values, wellbeing and individual and social development (Davis, 2015). The quality of experience in early childhood settings is important for enriching children's lives. It is also a matter of equity with high quality provision being most beneficial for the least advantaged children (Sylva et al, 2004). The international Sustainable Development Goal for 'Quality Education' includes the target: 'By 2030, ensure that all girls and boys have access to quality early childhood development, care and preprimary education ...' (United Nations, 2015). This global expansion of early childhood education and care raises many questions about the nature of provision, of what constitutes quality in different contexts and whether and how purposeful experiential learning can be promoted and supported in a wide variety of circumstances.

Effective experiential learning places great responsibility upon the teacher. Following children's interests in order to provide learning opportunities that are familiar, and yet also offer challenge, is never simple. An ambition to educate for sustainability 
adds a further layer of complexity, especially as topics such as global economic and social inequalities, conflict, climate change and threats to biodiversity are remote from the day to day lives of most children. Yet, in their daily interactions within physical and social environments children actively experiment and can also experience and reflect upon the consequences of their experimentation. Norðdahl and Jóhannesson (2016) use the example of a child building a sandcastle and learning how the wetness of the sand affects the construction process. For ECEfS, teachers can encourage children's communication with the environment to provoke what environmentalist Rachel Carson (1965) termed 'a sense of wonder'; excitement and awe at the beauty of the world. This links with Dewey's (1934) concept of aesthetic experience as something enriching and fulfilling, with characteristics of vitality and heightened awareness. Skilled adults may support children's doing and undergoing of activities in order to add breadth and depth to their everyday experiences. For example, a technique of noticing surroundings can be encouraged using 'sit spot' activities whereby children choose a space, usually outdoors in nature, as a place to sit still and become aware of everything that they see, hear, and feel.

Norðdahl and Jóhannesson (2016) found that Icelandic teachers believe that enjoyment of being in nature can raise environmental awareness and encourage positive attitudes and respect towards nature. With imagination, educators can go further and provide relevant, playful participatory activities that extend children's knowledge and experience and support understanding and protection of the natural world. An example of this is a bat conservation project undertaken in Alderholt Sunbeams Nursery in Dorset and Nakuru West Preschool in the Rift Valley of Kenya (Luff et al, 2015). Environmental educator, Zoe Miles, worked with the Sunbeams staff to develop a three-week integrated topic on the theme of bats involving music, movement, stories and crafts and 
incorporating all the areas of learning in the EYFS curriculum. This included an exciting family bat observation evening where heterodyne detectors were used to listen to the bat calls and the parents and children saw Pipistrelle and Noctule bats. The children in Dorset shared their experiences by sending video of their bat activities, plus a bat picture book and cuddly toy, to Kenya. In Kenya, children replicated some of the activities, using local recycled materials, and learned about the importance of bats for reducing numbers of disease-carrying mosquitoes and for pollinating food crops. In both countries, negative images of bats were addressed and some myths dispelled.

\section{Curiosity and Critical Thinking}

The bat conservation project was introduced to children by adults but raised many questions amongst the children about bats and bat behaviours. For example, children wanted to know whether bats were birds or animals, why they hung upside down and how they stayed up. This shows how educators can spark children's curiosity. Dann (2013) recognises such opportunities in the EYFS curriculum and reminds us that Dewey defined and analysed curiosity as moving from the energetic explorations of physical curiosity, via the questioning and investigations of social curiosity, to the more sustained and systematic problem solving of intellectual curiosity. For Dewey (1933), such curiosity is often learner-initiated and can be extended via processes of enquiry (looking for and finding meaning, independent thought, and questioning of the social world). This is important for future positive dispositions towards lifelong learning. It is also vital for the creative and critical thinking that is necessary for young children to solve present and future problems and that could equip them to face challenges with skills to ask questions and develop solutions.

Indeed, in terms of problem solving and being actively open to ideas, Dewey (1916/2007) argued that adults could learn from children: 
'With respect to the development of powers devoted to coping with specific scientific and economic problems we may say the child should be growing in manhood [sic]. With respect to sympathetic curiosity, unbiased responsiveness, and openness of mind, we may say that the adult should be growing into childlikeness'

Arjen Wals (2006) echoes this sentiment and advocates a return to the values and approaches of early childhood education to facilitate movement towards a more sustainable world: 'There are no dumb questions in kindergarten and there's always time for questions and questioning' (45).

The pre-schools of Reggio Emilia, Italy, provide an exemplar of a pedagogy based upon critical questioning strategies and careful listening. Dewey was amongst the theorists who inspired the Reggio Emilia approach to pre-school education, particularly with regard to the pedagogical approach involving dialogic, project based learning plus constant deliberation and reflection on the purposes of early childhood education (Moss, 2012). Insights from Dewey are also found in the aesthetic qualities of experience that are valued and promoted in Reggio Emilia (Cooper, 2012). The spaces are designed to facilitate explorations, investigations, communication and expression through different media. These media include waste materials from business and industry reclaimed and recycled as resources via the REMIDA centre, which promotes a culture of creative reuse of materials.

Closer to home, Cambridge Curiosity and Imagination is an organisation that invites creativity, and playful exploration of ideas with children and adults of different ages. The projects provide for engagement and experimentation in different indoor and outdoor locations and support a range of creative adventures. For example, in ' 37 Shadows: listening to children's stories from the woods' (Wilenski, 2012) documents children's stories that emerged from attentive and patient listening to children during their 
free play in a local woodland. They reveal the four and five year old authors' physical, social and intellectual curiosity (Dewey, 1933; Dann, 2013) as children create 'small stories engaging with big ideas' (Wilenski, 2012, 7) from their experiences of play in the woods.

\section{Experiences in Nature}

Outdoor experiences in nature are highly valued within early childhood education. This is shown by the growing popularity of the Forest School approach, including outdoor childcare and education settings where children spend most of their time outside in a natural environment (Knight, 2016). Dewey is amongst the educational theorists credited as a founder of this tradition of learning outdoors in nature (Elliott and Davis, 2009; Quay and Seaman, 2013). For Dewey, nature is not something external to human experience but rather humans are within and part of nature and exist in transaction with the natural world (Dewey, 1916; Hildebrand, 2008); and the natural world can be discovered through cooperative enquiry between students and teachers (Garrison et al, 2012). Outdoors in nature, too, young children have opportunities for learning from sensory experience of various phenomena, to a greater extent than can be achieved indoors.

Whilst, in early years education, education for sustainability has roots in environmental education and the valuing of outdoor play and learning, outdoor experience is not always linked explicitly to ECEfS or is linked in quite tenuous ways following a belief that time spent in contact with nature will lead to respect for the environment and concern for its preservation (Elliott and Davis, 2009; Davis, 2015; Norðdahl and Jóhannesson, 2016). Here, again, Dewey offers inspiration with a view of learning in, about and for nature that rejects simple, romantic notions of free play outdoors and offers instead opportunities for children to appreciate biodiversity and ecology, to 
'actually get a feeling for plants and animals, together with some real scientific knowledge' (Dewey, 1908, 185).

An example is via school gardening, whereby, children can gain experiences that spark interest in their environment via activities such as vegetable production. Ralston (2011), citing Dewey, suggests that gardening 'evokes wonder, freedom, patience and action in the child' and can be a 'gateway to fuller appreciation of nature' (4). Macdonald (2015) shows how gardening plays a part in the open curriculum framework, 'Foundations of Our Intentions', designed to support sustainability and holistic development at UniverCity Child Care. For example: a sense of belonging is created by looking after the garden, including participation by families in planting projects; living systems are understood by processes of composting and the life cycle of plants, observed and documented over time; respect is learned through caring for the garden; and boundaries are understood via understanding the conditions for growth of different plants and weeding and spacing of plants. Modes and methods for promoting learning are also discussed with the teachers being alert to opportunities for dialogue and taking time to observe the children's learning.

Klaar and Öhman $(2012,2014)$ illustrate in detail how teachers may guide learning processes when children young children are outdoors in nature. They use a Deweyan transactional approach to explore the interplay between the learner, teacher and environment and the content and qualities of the learning. Their close analysis of a toddlers coordinating physical actions in natural surroundings on icy and clay slopes (Klaar and Öhman, 2012); and of interactions in everyday activities (drinking juice during a trip to the forest, planting strawberry plants in the garden, handling a stone, and tackling a slide in the playground (Klaar and Öhman, 2014) reveal the multi-faceted guidance strategies used by the teacher to support learning in nature. Mackey (2011) also observed 
interactions, with slightly older children, at a kindergarten with an environmental programme and noted the children's capacity to gain knowledge, to make decisions and to act in relation to environmental and social issues.

\section{Democracy and Participation}

In experiential learning, both indoors and outside, democracy and participation are at the core. Dewey's view of the person in transaction with the environment presents a useful view of the child as acting upon and influencing the world around them. Even very young children can shape the environment that surrounds them as:

'... all education proceeds by the participation of the individual in the social consciousness of the race. This process begins unconsciously almost at birth, and is continually shaping the individual's powers, saturating his consciousness, forming his habits, training his ideas, and arousing his feelings and emotions.' (Dewey, 1897/1974, 427).

The participation and involvement of the child is a key element of democratic early childhood education. Cuffaro (1995) wrote of the importance of children as curriculum creators with their contribution to learning clearly evident. Teachers have to work alongside children and their interests and make connections with the wider world.

One example of this is via Philosophy for Children (Lipman et al, 1980) where pupil enquiries and critical thinking skills are fostered. Young children participate in collaborative thinking activities in which they respond to an imaginative challenge, such as deciding which fairy tale characters should be invited to a birthday party, Children have the opportunity to raise questions and to express and back up their viewpoints. Importantly, are encouraged to listen to and understand the ideas and opinions of their peers. In this participative process, the teacher acts as facilitator as children are exposed to differences in thinking and gain experience of active participation in negotiations. 
An important feature of ECEfS is recognition of children's participation as active learners, citizens and agents for societal change (Davis and Elliott, 2014; Engdahl, 2015). This is not always straightforward, as perceptions of childhood as a time of innocence and vulnerability can lead to reluctance to engage with problematic and difficult issues of ecological sustainability (Duhn, 2012). Educators, working within often risk-averse professional contexts, must support children to participate in complex matters that affect their lives, in both the present and future (ibid).

In their review of literature relating to education for sustainable development in early childhood, Hedefalk et al (2015) identify several research projects where children act for change in relation to sustainability. These are characterised by teachers' growing understandings of the importance of children being encouraged to think and act critically through processes of democratic teaching. Young children participate in decision making and act as co-researchers alongside their teachers. example is in the work of Ärlemalm-Hagsér and Sandberg (2011) where Swedish day care assistants, undertaking an in-service course, were shown to value children's viewpoints and involvement in learning as an aspect of sustainability linked with rights, democracy, gender equality and cultural diversity.

Engdahl's (2015) report of the OMEP World Project on ESD, published after the articles considered in the Hedefalk et al (2015) review, showed that adults tend to underestimate young children's knowledge of the world, their awareness of the state of the earth and their ability to consider complex problems such as pollution and climate change. In the various child-oriented action research and development projects, children from different parts of the world were given the opportunity to demonstrate their knowledge and ideas about environmental issues and to put forward suggestions for action. Children were 'valued as thinkers, problem-solvers and agents of change' 
(Engdahl, 2015, 363) and shown to be highly aware of the causes and consequences of problems and the responsibilities that people carry for sustainability.

A different perspective on young children's agency is offered by Caiman and Lundegård (2014) who utilise close analysis of video recordings of groups of children acting together to make a shelter to protect pea plants from heavy rainfall and to create an alternative nest for birds in a more peaceful place undisturbed by construction workers. Their explanation of agency is as something that the children achieve in their transactions with one another and the environment. The care that the children show and the ways in which they negotiate and act demonstrate their meaning making and decision taking for environmental sustainability. Notably, the teacher, present during the first scenario, remained in a listening role and allowed the children to maintain control of the process throughout.

\section{Classroom as Community}

So, agency goes beyond the initiative of individual learners to the creation of the early years classroom as community. For Dewey, education is primarily a social process in which the child participates through shared interests and tasks towards relevant common goals. Dewey's view of educational institutions as embryonic communities, built through processes of communication and shared action contributing to the development 'of a larger society which is worthy, lovely and harmonious' (Dewey, 1900, 24) offers an ideal that epitomises ECEfS. The sharing of experience in basic social activities, including practical experiences such as gardening, cooking, making and doing things, fosters understanding of moral and ethical roles and responsibilities towards others and the natural world. Thus, for Dewey, the school is a microcosm of wider society and a place where social and community values can be learned. 
In the $21^{\text {st }}$ century, too, educative experiences within the early years community, and reaching out to the locality, are influential for the growth of skills, values and attitudes for present and future moral conduct. Nursery schools, playgroups and other early years settings have long sought to nurture children and families through a community approach. Nevertheless, within a curriculum framework such as the EYFS, where there is a focus upon charting and promoting the progress of each unique child, there is a risk that individualism and independence can be in tension with community and interdependence. Cuffaro (1995) is clear that community does not override individuality but rather that individual interests and questions can become common concerns to which others can contribute ideas and information. MacDonald (2015), similarly, highlights potential for early childhood curricula that guide children towards a deep understanding of sustainability, rooted in self, family, school and community and promoted through active, collaborative, project based methods (such as the examples cited relating to gardening and composting, above).

Additionally, there is scope for the school or early years setting to make links with and participate in the surrounding community and to draw upon physical and social resources in the locality. This view is incorporated within place-based education, in which children learn to understand, value and care for the heritage, culture and landscape of the place where they live. Writing from their experience of educating for sustainability through work at Shelburne farms, in Vermont, Hoyler and Wellings (2013) explain that children who have opportunities to explore, connect with and appreciate the places where they live develop a sense of care for self, others and the environment. This can lead to work on local social and environmental projects and growing appreciation of wider national and global issues. 
Huggins and Siraj-Blatchford (2015), however, warn that sense of community must go beyond a local sense of place to promote and foster global citizenship, even at an early age. Rather than assuming that local actions will lead to future global action, they urge early recognition of global interconnectedness and a 'need to be thinking locally and acting globally as well as thinking globally and acting locally' (9). They give examples of dialogues developed through the British Council's Connecting Classrooms scheme and the OMEP partnership between preschools in Dorset and Kenya (the Bat Conservation project, mentioned above, stemmed from this latter initiative). In these projects local pre-school communities in both countries undertake projects, such as celebrating global handwashing day or recording journeys to school, and then compare and share knowledge, ideas and resources to learn from the different situations. This strengthens a sense of belonging within the local groups with potential for recognition of commonalities and differences and a sense of global interdependence.

\section{Conclusion}

In summary, I propose practical and research based approaches to early childhood education for sustainability that are underpinned, inspired and theorised by the work of Dewey. The task is ongoing and essential because our current work with young children will have important consequences:

'In directing the activities of the young, society determines its own future in determining that of the young. Since the young at a given time will at some later date compose the society of that period, the latter's nature will largely turn upon the direction children's activities were given at an earlier period' (Dewey 1916, 36).

It is with attention to this advice that I argue for experiential learning, including critical and creative thinking and experiences in nature, to inform a pedagogical approach to ECEfS that is participative, democratic and fosters a sense of local and global community. The essence of sustainability is meeting 'the needs of the present without 
compromising the ability of future generations to meet their own needs' (Brundtland, 1987, 43). This coheres with Dewey's view of the value of educative experiences in both the short term and the longer term and the significance of education for a worthwhile present and a hopeful future for individuals and for society.

Acknowledgement: Thanks to Anglia Ruskin University Research and Innovation Development Office for a Research Funding Observatory bursary that enabled the author to attend the conference John Dewey's "Democracy and Education" 100 Years On: Past, Present, and Future Relevance at Homerton College and Faculty of Education, University of Cambridge.

\section{Disclosure statement}

No potential conflicts of interest arise from the publication of this work.

\section{References}

Ärlemalm-Hagsér, E., and A. Sandberg. 2011. "Sustainable Development in Early

Childhood Education: In-service Students' Comprehension of the Concept.”

Environmental Education Research, 17 (2): 187-200.

doi:10.1080/13504622.2010.522704.

Brundtland, G. 1987. Our Common Future. The World Commission on Environment and Development. Oxford: Oxford University Press.

Caiman, C and I. Lundegård. 2014. "Pre-school Children's Agency in Learning for Sustainable Development." Environmental Education Research, 20 (4): 437-459. doi:10.1080/13504622.2013.812722.

Carson, R. 1965/no date. The Sense of Wonder. New York: Open Road Integrated Media. 
Commonwealth of Australia. Department of Education, Employment and Workplace Relations. 2009. Belonging, Being and Becoming: The Early Years Learning

Framework for Australia. Canberra: Commonwealth of Australia.

Cooper, M. 2012. “Is Beauty a Way of Knowing?” In The Hundred Languages of Children. 2nd ed., edited by C.P. Edwards, L. Gandini and G.E. Forman, 295-302.

Santa Barbara, CA: Praeger.

Cuffaro, H.K. 1995. Experimenting with the World. New York: Teachers College Press.

Dann, R. 2013. “Be Curious: Understanding 'Curiosity’ in Contemporary Curriculum Policy and Practice.” Education 3-13, 41 (6): 557-561.

doi:10.1080/03004279.2013.850256.

Davis, J.M. 2015. Young Children and the Environment. 2nd ed. Melbourne:

Cambridge University Press.

Davis, J.M. and S. Elliott. 2014. Research in Early Childhood Sustainability. London: Routledge.

DfE - Department for Education. 2017. Statutory Framework for the Early Years Foundation Stage. Accessed September 12017.

https://www.foundationyears.org.uk/files/2017/03/EYFS_STATUTORY_FRAMEWO $\underline{\text { RK_2017.pdf }}$

Dewey, J. 1897/1974. “My Pedagogic Creed.” In John Dewey on Education, edited by R.D. Archambault, 427-439. Chicago and London: University of Chicago Press.

Dewey. J. 1900. The School and Society. Chicago: University of Chicago Press. Dewey, J. 1908. “The Bearings of Pragmatism upon Education.” In John Dewey: The Middle Works 1899-1924, Volume 4: 1907-1909, edited by J.A. Boydston, 178-191. Carbondale: Southern Illinois University Press. 
Dewey, J. 1916/2007. Democracy and Education. Teddington, Middlesex: Echo Library.

Dewey, 1933/1998. How We Think. Boston, MA: Houghton Mifflin Company.

Duhn. I. 2012. “Making 'Place’ for Ecological Sustainability in Early Childhood Education.” Environmental Education Research, 18 (1): 19-29, doi:10.1080/13504622.2011.572162.

Elliott, S. and Davis, J. 2009. "Exploring the Resistance: An Australian Perspective on Educating for Sustainability in Early Childhood." International Journal of Early Childhood, 41 (2): 65-77. doi:10.1007/BF03168879.

Engdahl, I. 2015. "Early Childhood Education for Sustainability: The OMEP World Project.” International Journal of Early Childhood, 47 (3): 347-366. doi:10.1007/s13158-015-0149-6. EPSD - European Panel on Sustainable Development. 2010. “Taking Children Seriously - How the EU Can Invest in Early Childhood Education for a Sustainable Future.” Report No. 4 2010-12-17. Accessed January 282017. http://www.ufn.gu.se/digitalAssets/1324/1324488_epsd_report4.pdf Garrison, J. 2008. "Reconstructing Democracy and Recontextualising Deweyan Pragmatism.” In Reconstructing Democracy, Recontextualizing Dewey. Pragmatism and Interactive Constructivism in the Twenty-first Century, edited by J. Garrison, 1-17. Albany, New York: State University of New York Press.

Garrison, J., L. Hickman and D. Ikeda, D. 2014. Living as Learning. John Dewey in the $21^{\text {st }}$ Century. Cambridge, MA: Dialogue Path Press.

Hedefalk, M., J. Almqvist and L. Östman. 2015. "Education for Sustainable Development in Early Childhood Education: A Review of the Research Literature." 
Environmental Education Research, 21 (7): 975-990.

doi:10.1080/13504622.2014.971716.

Hildebrand, D.L. 2008. Dewey. Oxford: Oneworld Publications.

Hoyler, E. and L. Wellings. 2013. Cultivating Joy and Wonder. Accessed January 28 2017.

http://www.shelburnefarms.org/sites/default/files/cultivatingjoywonder_all_smaller.pdf

Huggins, V. and J. Siraj-Blatchford. 2015. “Education for Sustainable Development through International Partnerships.” Early Education Journal, 76: 14-15.

Klaar, S. and J. Öhman. 2012. “Action With Friction: A Transactional Approach on Toddlers' Physical Meaning Making of Natural Phenomena and Processes in Preschool." European Early Childhood Education Research Journal, 20 (3): 439-454. doi:10.1080/1350293X.2012.704765.

Klaar, S. and J. Öhman. 2014. "Doing, Knowing, Caring and Feeling: Exploring Relations Between Nature-Oriented Teaching and Preschool Children's Learning." International Journal of Early Years Education, 22 (1) 37-58, doi:10.1080/09669760.2013.809655

Knight, S. 2016. Forest School in Practice. London: Sage.

Lipman, M., A.M. Sharp and F.S. Oscanyan. 1980. Philosophy in the Classroom. Philadelphia: Temple University Press.

Luff, P., Z. Miles and C. Wangui. 2015. "A Bat Conservation Project in the UK and Kenya." Early Education Journal, 76: 14-15.

MacDonald, M. 2015. "Early Childhood Education and Sustainability: A Living Curriculum." Childhood Education, 91:5, 332-341.

doi:10.1080/00094056.2015.1090845. 
Mackey, G. 2011. “To Know, to Decide, to Act: The Young Child's Right to Participate in Action for the Environment." Environmental Education Research, 18 (4): 473-484. doi:10.1080/13504622.2011.634494.

Moss, P. 2012. "Micro-Project and Macro-Policy: Learning through Relationships.” In The Hundred Languages of Children. 2nd ed., edited by C.P. Edwards, L. Gandini and G.E. Forman, 101-113. Santa Barbara, CA: Praeger.

Norðdahl, K. and I.A. Jóhannesson. 2016. 'Let's Go Outside’: Icelandic Teachers' Views of Using the Outdoors." Education 3-13, 44:4, 391-406.

doi:10.1080/03004279.2014.961946.

Quay, J. and J. Seaman. 2013. John Dewey and Education Outdoors: Making Sense of the 'Educational Situation' through more than a Century of Progressive Reforms. Rotterdam: Sense Publishers.

Ralston, S.J. 2011. "It Takes a Garden Project: Dewey and Pudup on the Politics of School Gardening." Ethics and the Environment, 16 (2): 1-24.

Rodgers, C. 2002. "Defining Reflection: Another Look at John Dewey and Reflective Practice." Teachers College Record, 104 (4): 842-866.

Siraj-Blatchford, J., C. Mogharreban and E. Park. 2016. International Research on Education for Sustainable Development in Early Childhood. Switzerland: Springer. Siraj-Blatchford, J., K.C. Smith and I. Pramling Samuelsson. 2010. Education for Sustainable Development in the Early Years. Sweden: OMEP.

Sylva, K., E. Melhuish, P. Sammons, I. Siraj-Blatchford and B. Taggart. 2004. The Effective Provision of Pre-School Education Project: Final Report. Nottingham: DfES Publications.

Tickell, C. 2011. The Early Years: Foundations for Life, Health and Learning - An Independent Report on the Early Years Foundation Stage to Her Majesty's 
Government. Accessed January 282017.

https://www.gov.uk/government/uploads/system/uploads/attachment_data/file/180919/ DFE-00177-2011.pdf

UNESCO. 2008. "The Gothenburg Recommendations on Education for Sustainable

Development.” Accessed January 282017.

http://www.desd.org/gothenburg1\%20recommendations.pdf

United Nations. 2015. “Sustainable Development Goals.” Accessed January 282017.

http://www.un.org/sustainabledevelopment/sustainable-development-goals/

Wals, A.E.J. 2006. “The End of ESD...The Beginning of Transformative Learning -

Emphasizing the E in ESD." Proceedings of the Seminar on Education for Sustainable

Development, 42-59. Helsinki: Finnish UNESCO Commission.

Wilenski, D, 2012. 37 Shadows. Listening to children's stories from the woods.

Accessed January 282017.

http://www.cambridgecandi.org.uk/projects/footprints/37shadows\# 